\title{
Correction to: Barriers and facilitating factors in the prevention of diabetes type II and gestational diabetes in vulnerable groups: protocol for a scoping review
}

Jessica Breuing ${ }^{1 *}$, Dawid Pieper ${ }^{1}$, Annika Lena Neuhaus ${ }^{1}$, Simone Heß ${ }^{1}$ Lena Lütkemeier ${ }^{2}$, Fabiola Haas², Mark Spiller ${ }^{2}$ and Christine Graf ${ }^{2}$

\section{Correction to: Syst Rev}

https://doi.org/10.1186/s13643-018-0919-y

Following publication of the original article [1], the authors reported an error in Table 1 as the wrong table was used. The inclusion criteria of the scoping review has been corrected in Table 1 here. Please see below. The authors would like to apologize for this error.

\section{Author details}

${ }^{1}$ Institute for Research in Operative Medicine (IFOM), Faculty of Health, Department of Medicine, Witten/Herdecke University, Ostmerheimer Str. 200, Building 38, 51109 Cologne, Germany. ${ }^{2}$ Institute of Movement and Neurosciences, German Sport University Cologne, Am Sportpark Müngersdorf 6, 50933 Cologne, Germany

Published online: 22 January 2019

\section{Reference}

1. Breuing J, Pieper D, Neuhaus AL, Heß S, Lütkemeier L, Haas F, Spiller M, Graf

C. Barriers and facilitating factors in the prevention of diabetes type II and gestational diabetes in vulnerable groups: protocol for a scoping review. Syst Rev. 2018;7:245. https://doi.org/10.1186/s13643-018-0919-y.
Table 1 PCC (Population, Concept, Context)

\begin{tabular}{|c|c|c|}
\hline \multirow[t]{11}{*}{$\bar{P}$} & \multirow{3}{*}{$\begin{array}{l}\text { Diabetes mellitus } \\
\text { type } 2 \text { or gestation } \\
\text { diabetes }\end{array}$} & Type 2 diabetes mellitus \\
\hline & & Gestational diabetes mellitus \\
\hline & & $\begin{array}{l}\text { People at risk of developing } \\
\text { diabetes mellitus or gestational } \\
\text { diabetes mellitus }\end{array}$ \\
\hline & \multirow[t]{8}{*}{$\begin{array}{l}\text { Vulnerable patients/ } \\
\text {-groups }\end{array}$} & $\begin{array}{l}\text { Elderly, older people, seniors } \\
>65 \text { years }\end{array}$ \\
\hline & & Disabled people \\
\hline & & $\begin{array}{l}\text { People in need of care, residents } \\
\text { of a nursing home }\end{array}$ \\
\hline & & Unemployed people \\
\hline & & $\begin{array}{l}\text { Refugees/migrants as well as ethnic } \\
\text { groups (e.g. African Americans or } \\
\text { Hispanics) }\end{array}$ \\
\hline & & Homeless people \\
\hline & & $\begin{array}{l}\text { Drug/substance abusers (excluding } \\
\text { nicotine abuse/smoking) }\end{array}$ \\
\hline & & Low socio-economic status \\
\hline \multirow[t]{3}{*}{ C } & Prevention & Primary/ secondary/ tertiary prevention \\
\hline & \multirow[t]{2}{*}{$\begin{array}{l}\text { Barriers and facilitating } \\
\text { factors }\end{array}$} & $\begin{array}{l}\text { Definition of barriers and motivating } \\
\text { aspects e.g. language, costs, religion, } \\
\text { ethnic background, low income, } \\
\text { social and health support }\end{array}$ \\
\hline & & $\begin{array}{l}\text { Solutions to exploit barriers and } \\
\text { support solutions e.g. materials and } \\
\text { manpower, use of media, insurance }\end{array}$ \\
\hline C & > 2008; WHO stratum A & \\
\hline Other & all types of studies; all & nguages; available in full text version \\
\hline
\end{tabular}

The PPC (Population, Concept, Context) mnemonic illustrates the eligibility criteria for the scoping review. Additionally to the classic PPC mnemonic there are other criteria regarding study types, languages and the availability of the full text version

* Correspondence: jessica.breuing@uni-wh.de

${ }^{1}$ Institute for Research in Operative Medicine (IFOM), Faculty of Health,

Department of Medicine, Witten/Herdecke University, Ostmerheimer Str. 200,

Building 38, 51109 Cologne, Germany

Full list of author information is available at the end of the article

(c) The Author(s). 2019 Open Access This article is distributed under the terms of the Creative Commons Attribution 4.0 International License (http://creativecommons.org/licenses/by/4.0/), which permits unrestricted use, distribution, and reproduction in any medium, provided you give appropriate credit to the original author(s) and the source, provide a link to the Creative Commons license, and indicate if changes were made. The Creative Commons Public Domain Dedication waiver (http://creativecommons.org/publicdomain/zero/1.0/) applies to the data made available in this article, unless otherwise stated. 